\title{
Faktor yang Mempengaruhi Pus Terhadap Pemilihan Metode Kontrasepsi Mow di Wilayah Kerja Puskesmas Cidempet Indramayu
}

\author{
Factors Affecting Pus on the Selection of Mow Contraception Methods in the Work Area of \\ Cidempet Health Center Indramayu
}

Indah Oktaviani $^{1}$, Sutangi ${ }^{2}$, Tayong Siti Nurbaeti ${ }^{3}$

1,2,3 Program Studi Kesehatan Masyarakat
e-mail: t.siti.nurbaeti@gmail.com

\section{Abstrak}

Pasangan usia subur (PUS) adalah pasangan suami istri yang terkait dalam perkawinan yang sah, yang pasangan wanita berusia antara 15 - 49 tahun, karena kelompok ini merupakan pasangan aktif melakukan hubungan seksual dan setiap kegiatan seksual dapat mengakibatkan kehamilan.

Rancangan penelitian yang digunakan adalah Penelitian deskriptif analitik yang dilakukan dengan pendekatan Case Control. Analisis deskriptif adalah untuk melihat atau menganalisis dinamika Hubungan antara Karakteristik PUS tentang kontrasepsi dengan Pemeilihan Alat Kontrasepsi MOW

Pada penelitian ini didapatkan Hasil penelitian diketahui bahwa dari 128 responden yang menggunakan alat kontrasepsi MOW sebagian besar adalah berpengetahuan baik yaitu sebanyak 46 responden $79,3 \%$, dari 128 responden yang menggunakan alat kontrasepsi MOW sebagian besar adalah berpendidikan tinggi yaitu sebanyak 48 orang $(71,6 \%)$, dari 128 responden yang menggunakan alat kontrasepsi MOW sebagian besar adalah ekonomi atas yaitu sebanyak 47 orang $(70,2 \%)$.

Kata kunci : Pengetahuan, Pendidikan, Ekonomi, Pemilihan alat kontrasepsi

\section{Abstract}

Fertile age couples (PUS) are related couples in a legal marriage, whose female partners are between the ages of 15 and 49 , because this group is an active partner for sexual intercourse and any sexual activity can lead to pregnancy.

The research design used was analytic descriptive research conducted with a Case Control approach. Descriptive analysis is to see or analyze the dynamics of the relationship between EFA characteristics about contraception with the selection of MOW contraceptives.

In this study, the results of the study revealed that of 128 respondents who used MOW contraceptives, most of them were well-informed, as many as 46 respondents $79.3 \%$, out of 128 respondents who used MOW contraceptives, most of them were highly educated, as many as 48 people $(71,6 \%)$, out of 128 respondents who use MOW contraceptives, most of them are upper economies, as many as 47 people $(70.2 \%)$.

Keywords: Knowledge, Education, Economics, Selection of contraceptives

\section{Pendahuluan}

Banyak hal yang mempengaruhi akseptor KB sebagai pertimbangan dalam memilih alat kontrasepsi antara lain adalah pertimbangan medis, latar belakang sosial budaya, sosial ekonomi, pengetahuan, pendidikan, dan jumlah anak yang diinginkan. Disamping ada efek samping yang merugikan dari suatu alat kontrasepsi juga berpengaruh dalam menyebabkan bertambah atau berkurangnya akseptor suatu alat kontrasepsi.

Data WHO menunjukkan bahwa pengguna alat kontrasepsi implant di seluruh dunia masih di bawah alat kontrasepsi suntik, pil, dan IUD, terutama di negara-negara berkembang. Persentase pengguna alat kontrasepsi suntik yaitu $35,3 \%$, pil yaitu $30,5 \%$, IUD yaitu $15,2 \%$ sedangkan implant di bawah $10 \%$ yaitu $7,3 \%$, dan alat kontrasepsi lainnya sebesar $11,7 \%$

Berdasarkan data Susenas tahun 2012 sampai 2015 tentang Pemakaian Kontrasepsi Cara Modern, di gambarkan sebagai berikut bahwa sebagian besar PUS peserta KB di Indonesia masih mengandalkan kontrasepsi suntikan $(59,57 \%)$ dan pil $(20,71 \%)$ dari total pengguna KB. Sedangkan persentase pengguna Metode Kontrasepsi Jangka Panjang (MKJP) terbesar adalah pengguna IUD $(7,30 \%)$ dan Susuk KB (6,21\%). Adapun peserta $\mathrm{KB}$ pria yang ada hanya mencapai sekitar $1,27 \%(\mathrm{MOP}=0,27 \%$ dan Kondom $=$ $1 \%)$.

Peserta KB aktif di wilayah kerja puskesmas Cidempet yaitu 6693 jiwa dimana yang menggunakan KB IUD sebanyak 190 jiwa, MOP 194 jiwa, Implant 471 jiwa, Pil 
2496 jiwa. Dari data Dinas Pengendalian Penduduk dan Keluarga. Berencana (DPPKB) Kabupaten Indramayu tahun 2015, bahwa akseptor KB aktif diseluruh kecamatan yang ada di wilayah kabupeten indramayu 308.774 orang, diantaranya suntik 160.174 orang, pil 105.025 orang, implant 19.003 orang, kondom 2964 orang MOP 5231 orang, MOW 5802 orang, IUD 10.545 orang. ${ }^{1}$

\section{Metode}

Rancangan penelitian yang digunakan adalah Penelitian deskriptif analitik yang dilakukan dengan pendekatan Case Control. Analisis deskriptif adalah untuk melihat atau menganalisis dinamika Hubungan antara Karakteristik PUS tentang kontrasepsi dengan Pemeilihan Alat Kontrasepsi MOW.

Penelitian dilaksanakan di Wilayah Kerja Puskesmas Cidempet Kecamatan Arahan Kabupaten Indramayu tahun 2018. menyatakan bahwa yang dimaksud dengan populasi adalah wilayah generalisasi yang terdiri atas obyek/subyek yang mempunyai kuantitas dan karakteristik tertentu yang ditetapkan oleh peneliti untuk dipelajari dan kemudian ditarik kesimpulannya. ${ }^{2}$ Populasi penelitian disini adalah aseptor aktif MOW sebanyak 183 dan sebagai kasus kontrol diambil dari Pasangan Usia Subur (PUS) di wilayah kerja Puskesmas Cidempet.

Sampel atau contoh (monster) adalah sebagian individu yang diselidiki dari keseluruhan individu penelitian.Menurut Suharsimi. ${ }^{3}$ Sampel adalah sebagian atau yang mewakili yang ditrliti. sampel adalah sebagian yang diambil dari keseluruhan objek yang diteliti dan dianggap mewakili populasi. ${ }^{4}$

Untuk menjaga representatif dari hasil penelitian dan proporsi antara Karakteristik PUS tentang kontrasepsi dengan Pemeilihan Alat Kontrasepsi di Wilayah Kerja Puskesmas Cidempet Kecamatan Arahan Kabupaten Indramayu, maka diambil sampel sebanyak 64 orang (sebagai kasus) dari yang aktif menggunakan alat kontrasepsi MOW, dan sebagai kontrol diambil sebanyak 64 orang PUS (sebagai control) di wilayah kerja Puskesmas Cidempet.

\section{Hasil Penelitian}

\section{Analisis Univariat}

Hasil univariat dalam penelitian ini meliputi karakteristik meliputi pengetahuan, pendidikan dan tingkat ekonomi. Hasil penelitian univariat disajikan dalam tabel 1-3.

\section{Tabel 1. Pengetahuan Aseptor KB MOW}

\begin{tabular}{clcc}
\hline No & Pengetahuan & Frekuensi & Presentase\% \\
\hline $\mathbf{1}$ & Baik & 58 & 45,3 \\
$\mathbf{2}$ & Kurang & 70 & 54,7 \\
\hline & Jumlah & 128 & 100 \\
\hline
\end{tabular}

Diperoleh hasil bahwa dari 128 responden sebagian besar berpengetahuan kurang yaitu sebanyak 70 responden $54,7 \%$ dan responden yang berpengetahuan baik yaitu sebanyak 58 respoden $45,3 \%$.

\section{Tabel 2. Pendidikan Aseptor KB MOW}

\begin{tabular}{clcc}
\hline No & Pendidikan & Frekuensi & Prosentase $\%$ \\
\hline $\mathbf{1}$ & Tinggi & 67 & 52,3 \\
$\mathbf{2}$ & Rendah & 61 & 47,7 \\
\hline & Jumlah & 128 & 100 \\
\hline
\end{tabular}

Diperoleh hasil bahwa dari 128 responden sebagian besar pendidikan tinggi yaitu sebanyak 67 responden 52,3\% dan responden yang pendidikan rendah yaitu sebanyak 61 respoden $47,7 \%$.

\section{Tabel 3. Ekonomi Aseptor KB MOW}

\begin{tabular}{clcc}
\hline No & Ekonomi & Frekuensi & Presentase\% \\
\hline $\mathbf{1}$ & Atas & 61 & 47,7 \\
$\mathbf{2}$ & Bawah & 67 & 52,3 \\
\hline & Jumlah & 128 & 100 \\
\hline
\end{tabular}

Diperoleh hasil bahwa dari 128 responden sebagian besar ekonomi bawah yaitu sebanyak 67 responden 52,3\% dan responden yang ekonomi atas yaitu sebanyak 61 respoden $47,7 \%$. 


\section{Analisis Bivariat}

Hasil bivariatt dalam penelitian ini meliputi karakteristik meliputi hubungan pengetahuan PUS hubungan pendidikan dan hubungan tingkat ekonomi aseptor KB MOW terhadap dengan Pemilihan Kontarsepsi. Hasil penelitian bivariat disajikan dalam tabel 4-6.
Hubungan antara tingkat pengetahuan PUS dengan pemilihan alat kontrasepsi MOW

Responden yang mempunyai pengetahuan baik sebanyak 58 orang $(45,3 \%)$ yang terdiri dari 46 orang $(79,3 \%)$ pada kasus dan 12 orang $(20,7 \%)$ pada kontrol, hasil tersebut dapat dilihat dalam tabel 4 berikut ini:

Tabel 4. Hubungan antara Tingkat Pengetahuan PUS dengan Pemilihan Alat Kontrasepsi MOW di kecamatan Arahan Kabupaten Indramayu

\begin{tabular}{|c|c|c|c|c|c|c|}
\hline \multirow{2}{*}{ No } & \multirow{2}{*}{ Pengetahuan } & \multicolumn{2}{|c|}{$\begin{array}{c}\text { Pemilihan Alat } \\
\text { Kontrasepsi }\end{array}$} & \multirow{2}{*}{ Jumlah } & \multirow{2}{*}{ P-value } & \multirow{2}{*}{ OR } \\
\hline & & MOW & $\begin{array}{l}\text { Bukan } \\
\text { MOW }\end{array}$ & & & \\
\hline 1 & Baik & $\begin{array}{c}46 \\
793 \%\end{array}$ & $\begin{array}{c}12 \\
207 \%\end{array}$ & $\begin{array}{c}58 \\
100^{\circ}\end{array}$ & \multirow[b]{2}{*}{0,000} & \\
\hline 2 & Kurang & $\begin{array}{c}19.3 \% \\
18 \\
25,7 \%\end{array}$ & $\begin{array}{c}20,7 \% \\
52 \\
74, .3 \%\end{array}$ & $\begin{array}{c}100 \% \\
70 \\
100 \%\end{array}$ & & $\begin{array}{c}11,07 \\
4\end{array}$ \\
\hline \multicolumn{2}{|r|}{ Jumlah Total \% } & $\begin{array}{c}64 \\
50,0 \% \\
\end{array}$ & $\begin{array}{c}64 \\
50,0 \% \\
\end{array}$ & $\begin{array}{c}128 \\
100 \% \\
\end{array}$ & & \\
\hline
\end{tabular}

Sedangkan responden yang memliki pengetauan kurang sebanyak 70 orang $(54,7 \%)$ yang terdiri dari 18 orang $(25,7 \%)$ pada kasus dan 52 orang $(74,3 \%)$ pada kontrol. p-Value sebesar 0,000 ada hubungan yang signifikan antara tingkat pengetahuan PUS dengan pemilihan alat kontrasepsi MOW. Untuk melihat tingkat kekuatan hubungan dapat dilihat dari nilai Odds Ratio (OR), diperoleh OR yaitu 11,074 (OR > 1) artinya pengetahuan PUS merupakan faktor resiko dalam pemilihan alat kontrasepsi MOW

Tabel 5. Hubungan antara tingkat pendidikan PUS dengan pemilihan alat kontrasepsi MOW di kecamatan Arahan Kabupaten Indramayu

\begin{tabular}{|c|c|c|c|c|c|c|}
\hline \multirow[b]{2}{*}{ No } & \multirow[b]{2}{*}{ Pendidikan } & \multicolumn{2}{|c|}{ Pemilihan alat kontrasepsi } & \multirow[b]{2}{*}{ Jumlah } & \multirow[b]{2}{*}{ P-value } & \multirow[b]{2}{*}{ OR } \\
\hline & & MOW & $\begin{array}{l}\text { Bukan } \\
\text { MOW }\end{array}$ & & & \\
\hline \multirow{2}{*}{1} & Tinogi & 48 & 19 & 67 & \multirow{3}{*}{0,000} & \multirow{3}{*}{7,105} \\
\hline & 1111ggi & $71,6 \%$ & $28,4 \%$ & $100 \%$ & & \\
\hline 2 & Rendah & $\begin{array}{c}16 \\
26.3 \%\end{array}$ & $\begin{array}{c}45 \\
73.7 \%\end{array}$ & $\begin{array}{c}61 \\
100 \%\end{array}$ & & \\
\hline \multicolumn{2}{|c|}{ Jumlah Total \% } & $\begin{array}{c}64 \\
50,0 \%\end{array}$ & $\begin{array}{c}64 \\
50,0 \%\end{array}$ & $\begin{array}{c}128 \\
100 \%\end{array}$ & & \\
\hline
\end{tabular}

Responden yang mempunyai pendidikan tinggi sebanyak 67 orang $(45,3 \%)$ yang terdiri dari 48 orang $(71,6 \%)$ pada kasus dan 19 orang $(28,4 \%)$ pada kontrol. Sedangkan responden yang memliki pendidikan rendah sebanyak 61 orang $(54,7 \%)$ yang terdiri dari
16 orang $(26,3 \%)$ pada kasus dan 45 orang $(73,7 \%)$ pada kontrol.

Disamping itu $p$-Value pada tabel diatas sebesar 0,000 sehingga lebih kecil dari 0,05. Dengan demikian, ada hubungan yang signifikan antara tingkat pendidikan PUS 
dengan pemilihan alat kontrasepsi MOW di kecamatan Arahan Kabupaten Indramayu tahun 2018

Untuk melihat tingkat kekuatan hubungan dapat dilihat dari nilai Odds Ratio (OR), diperoleh OR yaitu 7,105 (OR > 1) artinya pendidikan PUS merupakan faktor resiko dalam pemilihan alat kontrasepsi MOW di kecamatan Arahan Kabupaten Indramayu tahun 2018

Tabel 6. Hubungan antara tingkat penghasilan PUS dengan pemilihan alat kontrasepsi MOW di kecamatan Arahan Kabupaten Indramayu

\begin{tabular}{|c|c|c|c|c|c|c|}
\hline \multirow[b]{2}{*}{ No } & \multirow[b]{2}{*}{ Ekonomi } & \multicolumn{2}{|c|}{ Pemilihan alat kontrasepsi } & \multirow[b]{2}{*}{ Jumlah } & \multirow[b]{2}{*}{$\begin{array}{c}P- \\
\text { value }\end{array}$} & \multirow[b]{2}{*}{ OR } \\
\hline & & MOW & $\begin{array}{l}\text { Bukan } \\
\text { MOW }\end{array}$ & & & \\
\hline \multirow{2}{*}{1} & $\Delta$ tos & 47 & 14 & 61 & \multirow{4}{*}{0,000} & \multirow{4}{*}{9,874} \\
\hline & Atas & $70,2 \%$ & $29,8 \%$ & $100 \%$ & & \\
\hline \multirow{2}{*}{2} & Bawah & 17 & 50 & 67 & & \\
\hline & Dawan & $27,9 \%$ & $72,1 \%$ & $100 \%$ & & \\
\hline \multicolumn{2}{|c|}{ Jumlah Total \% } & $\begin{array}{c}64 \\
50,0 \%\end{array}$ & $\begin{array}{c}64 \\
50,0 \%\end{array}$ & $\begin{array}{c}128 \\
100 \%\end{array}$ & & \\
\hline
\end{tabular}

Berdasarkan hasil SPSS dibawah diketahui bahwa responden yang mempunyai ekonomi atas sebanyak 67 orang $(45,3 \%)$ yang terdiri dari 47 orang $(70,2 \%)$ pada kasus dan 14 orang $(29,8 \%)$ pada kontrol. Sedangkan responden yang memliki ekonomi bawah sebanyak 67 orang $(54,7 \%)$ yang terdiri dari 17 orang $(27,9 \%)$ pada kasus dan 50 orang $(72,1 \%)$ pada kontrol.

Disamping itu $p$-Value pada tabel diatas sebesar 0,000 sehingga lebih kecil dari 0,05. Dengan demikian, ada hubungan yang signifikan antara tingkat ekonomi PUS dengan pemilihan alat kontrasepsi MOW di kecamatan Arahan Kabupaten Indramayu tahun 2018

Untuk melihat tingkat kekuatan hubungan dapat dilihat dari nilai Odds Ratio (OR), diperoleh OR yaitu 9,874 (OR > 1) artinya ekonomi PUS merupakan faktor resiko dalam pemilihan alat kontrasepsi MOW di kecamatan Arahan Kabupaten Indramayu tahun 2018

\section{Pembahasan \\ Pengetahuan}

Pengetahuan adalah hasil " Tahu" dan ini terjadi setelah orang melakukan pengindraan terhadap suatu objek tertentu. Pengindraan terjadi melalui panca indra manusia, yakni indra penglihatan, pendengaran, penciuman, rasa dan raba. Sebagian besar pengetahuan diperoleh melalui mata dan telinga. ${ }^{6}$

Hasil penelitian diketahui bahwa dari 128 responden yang menggunakan alat kontrasepsi MOW sebagian besar adalah berpengetahuan baik yaitu sebanyak 46 responden $79,3 \%$ Hal ini menunjukan bahwa pengetahuan baik lebih besar pengaruhnya terhadap pemilihan alat kontrasepsi MOW dibandingkan dengan pendidikan kurang yaitu sebanyak 18 orang $(25,7 \%)$

\section{Pendidikan}

Pendidikan formal adalah pendidikan yang ditempuh melalui jalur sekolah seperti SD,SMP,SMA/SMK, Perguruan Tinggi. Karena pendidikan itu adalah suatu proses maka dengan sendirinya mempunyai masukan dan keluaran. Masukan proses pendidikan adalah sasaran pendidikan atau anak didik yang mempunyai karakteristik. Sedangkan keluaran proses pendidikan adalah tenaga atau lulusan yang mempunyai kualifikasi tertentu yang sesuai dengan tujuan pendidikan institusi yang bersangkutan. ${ }^{7}$ Hasil penelitian diketahui bahwa dari 128 responden yang menggunakan alat kontrasepsi MOW sebagian besar adalah berpendidikan tinggi yaitu sebanyak 48 orang $(71,6 \%)$ Hal ini menunjukan bahwa 
berpendidikan tinggi lebih besar pengaruhnya terhadap pemilihan alat kontrasepsi MOW dibandingkan dengan pendidikan kurang yaitu sebanyak 16 orang $(26,3 \%)$

\section{Ekonomi}

Biaya yang dikeluarkan dapat berhubungan dengan jangkauan terhadap calon aseptor. Semakin mahal harganya semakin terbatas aseptor untuk mendatangi sarana pelayanan untuk memilih alat kontrasepsi tertentu. ${ }^{8}$

Hasil penelitian diketahui bahwa dari 128 responden yang menggunakan alat kontrasepsi MOW sebagian besar adalah ekonomi atas yaitu sebanyak 47 orang $(70,2 \%)$. Hal ini menunjukan bahwa ekonomi atas lebih besar pengaruhnya terhadap pemilihan alat kontrasepsi MOW dibandingkan dengan ekonomi bawah yaitu sebanyak 17 orang $(27,9 \%)$.

\section{Hubungan Pengetahuan Pus dengan Pemilihan Alat Kontrasepsi Mow}

Hasil penelitian diatas diketahui bahwa responden yang mempunyai pengetahuan baik sebanyak 58 orang $(45,3 \%)$ yang terdiri dari 46 orang $(79,3 \%)$ pada kasus dan 12 orang (20,7\%) pada kontrol. Sedangkan responden yang memliki pengetauan kurang sebanyak 70 orang $(54,7 \%)$ yang terdiri dari 18 orang $(25,7 \%)$ pada kasus dan 52 orang $(74,3 \%)$ pada kontrol.

Disamping itu $p$-Value pada tabel diatas sebesar 0,000 sehingga lebih kecil dari 0,05. Dengan demikian, ada hubungan yang signifikan antara tingkat pengetahuan PUS dengan pemilihan alat kontrasepsi MOW di kecamatan Arahan Kabupaten Indramayu tahun 2018.

Pengetahuan terhadap alat kontrasepsi pada masyarakat sudah tidak asing lagi terutama pada ibu-ibu mengenai alat kontrasepsi MOW tersebut sudah tidak tahu lagi dibicarakan namun pengetahuan yang sudah ada pada masyarakat hanya sebatas tahu, jika mereka merasa perlu lebih tahu mengenai alat kontrasepsi maka mereka akan pergi ke tempat pelayanan kesehatan.

Menurut asumsi peneliti dengan melihat hasil pengelolahan data tersebut menunjukkan bahwa responden berpengetahuan tinggi dalam pemilihan metode kontrasepsi MOW sehingga kebanyakan responden memilih metode kontrasepsi efektif dalam memilih metode kontrasepsi. Pengetahuan akseptor KB sangat erat kaitannya terhadap pemilihan alat kontrasepsi, karena dengan adanya pengetahuan yang tinggi terhadap metode kontrasepsi tertentu akan merubah cara pandang akseptor dalam menentukan kontrasepsi yang paling sesuai dan efektif digunakan sehingga membuat pengguna $\mathrm{KB}$ lebih nyaman terhadap kontrasepsi tersebut dan dengan pengetahuan yang tinggi dapat menghindari kesalahan dalam pemilihan metode kontrasepsi yang paling sesuai bagi pengguna itu sendiri.

Pengetahuan adalah hasil " Tahu" dan ini terjadi setelah orang melakukan pengindraan terhadap suatu objek tertentu. Pengindraan terjadi melalui panca indra manusia, yakni indra penglihatan, pendengaran, penciuman, rasa dan raba. Sebagian besar pengetahuan diperoleh melalui mata dan telinga. ${ }^{6}$

Berdasarkan hasil wawancara peneliti dengan responden pada saatpenelitian, hal tersebut disebabkan karena responden tidak mau tahu tentang $\mathrm{KB}$ selain yang digunakannya, walaupun responden masih ada yang berpengetahuan rendah tetapi kebanyakan dari mereka menggunakan metode kontrasepsi sederhana jadi tidak semua yang berpengetahuan tinggi tepat dalam menggunakan metode kontrasepsi.

\section{Hubungan pendidikan PUS dengan pemilihan alat kontrasepsi MOW.}

Pendidikan merupakan salah satu kebutuhan dasar manusia yang sangat diperlukan dan memiliki pengaruh pada peningkatan kemampuan berpikir, dengan 
kata lain seseorang yang berpendidikan lebih tinggi akan dapat mengambil keputusan yang lebih rasional, umumnya terbuka untuk menerima perubahan atau hal baru dibandingkan dengan individu yang berpendidikan lebih rendah.

Pendidikan adalah upaya persuasi atau pembelajaran kepada masyarakat, agar masyarakat mau melakukan tindakan-tindakan (praktik) untuk memelihara (mengatasi masalah-masalah), dan meningkatkan kesehatannya. Perubahan atau tindakan pemeliharaan dan peningkatan kesehatanyang dihasilkan oleh pendidik kesehatan ini didasarkan kepada pengetahuan dan kesadarannya melalui proses pembelajaran, sehingga prilaku tersebut diharapkan akan berlangsung lama (long lasting), dan menetap karena didasari oleh kesadaran. ${ }^{8}$

Hasil penelitian diatas diketahui bahwa responden yang mempunyai pendidikan tinggi sebanyak 67 orang $(45,3 \%)$ yang terdiri dari 48 orang $(71,6 \%)$ pada kasus dan 19 orang $(28,4 \%)$ pada kontrol. Sedangkan responden yang memliki pendidikan rendah sebanyak 61 orang $(54,7 \%)$ yang terdiri dari 16 orang $(26,3 \%)$ pada kasus dan 45 orang $(73,7 \%)$ pada kontrol.

Disamping itu $p$-Value pada tabel diatas sebesar 0,000 sehingga lebih kecil dari 0,05. Dengan demikian, ada hubungan yang signifikan antara tingkat pendidikan PUS dengan pemilihan alat kontrasepsi MOW di kecamatan Arahan Kabupaten Indramayu tahun 2018.

Pendidikan berarti bimbingan yang diberikan seseorang kepada orang lain terhadap sesuatu hal agar mereka dapat memahaminya. Tidak dapat dipungkiri bahwa semakin tinggi pendidikan seseorang, maka semakin mudah pula mereka menerima informasi. Pada akhirnya, makin banyak pula pengetahuan yang dimilikinya, sebaliknya jika seseorang memiliki tingkat pendidikan yang rendah, maka akan menghambat perkembangan sikap seseorang terhadap penerimaan, informasi dan nilainilai yang baru dipekenalkan. ${ }^{12}$

Menurut asumsi peneliti dengan melihat hasil pengelolahan data tersebut menunjukkan bahwa responden berpendidikan dasar dalam pemilihan metode kontrasepsi sehingga kebanyakan responden memilih metode kontrasepsi sederhana. pendidikan akan mempengaruhi sikap seseorang dalam pengambilan keputusan karena semakin tinggi tingkat pendidikan akan semakin rasional dalam pengambilan keputusan hal ini juga akan berlaku dalam pengambilan keputusan untuk memilih metode kontrasepsi yang sesuai, tepat dan efektif.

Berdasarkan hasil wawancara peneliti dengan responden pada saat penelitian, di desa tersebut hanya sedikit yang berpendidikan tinggi kebanyakan dari mereka berpendidikan dasar, jadi pada saat melakukan wawancara hanya sedikit dari mereka yang mau mengatakan kontrasepsi apa yang mereka ppakai, sehingga sulit untuk mereka mendapatkan informasi.

\section{Hubungan ekonomi PUS dengan pemilihan alat kontrasepsi MOW.}

Hukum pasar menunjukan bahwa pelayanan yang baik dengan harga yang tepat akan menarik lebih banyak pasien, dalam pemasaran social KB biaya dikaitkan dengan penggunaan jasa pelayanan dan pemakaian alat kontrasepsi. Biaya yang dikeluarkan dapat berhubungan dengan jangkauan terhadap calon aseptor. Semakin mahal harganya semakin terbatas aseptor untuk mendatangi sarana pelayanan untuk memilih alat kontrasepsi tertentu. ${ }^{9}$

Hasil penelitian diatas diketahui bahwa responden yang mempunyai ekonomi atas sebanyak 67 orang $(45,3 \%)$ yang terdiri dari 47 orang $(70,2 \%)$ pada kasus dan 14 orang $(29,8 \%)$ pada kontrol. Sedangkan responden yang memliki ekonomi bawah sebanyak 67 orang $(54,7 \%)$ yang terdiri dari 17 orang $(27,9 \%)$ pada kasus dan 50 orang $(72,1 \%)$ 
pada kontrol.

Disamping itu $p$-Value pada tabel diatas sebesar 0,000 sehingga lebih kecil dari 0,05. Dengan demikian, ada hubungan yang signifikan antara tingkat ekonomi PUS dengan pemilihan alat kontrasepsi MOW di kecamatan Arahan Kabupaten Indramayu tahun 2018.

Ada hubungan yang bermakna antara ekonomi dengan pemilihan alat kontrasepsi, $\mathrm{p}$ value $0,005{ }^{10}$ Hal ini disebabkan karena mereka beranggapan bahwa didalam pemilihan alat kontrasepsi sebaiknya memang harus dilihat dari kapasitas kemampuan mereka untuk membeli kontrasepsi tersebut. Sehingga pemakaian kontrasepsi tidak dirasa memberatkan bagi si penggunanya. Hal ini sesuai dengan teori yang menyebutkan bahwa status ekonomi suatu keluarga sangat berpengaruh terhadap pemilihan kontrasepsi. Sosial Ekonomi/Penghasilan merupakan hak yang diterima atau yang didapat untuk memenuhi penghidupan yang layak. Sosial Ekonomi/Penghasilan adalah kemampuan seseorang untuk memenuhi kebutuhan hidup. Semakin tinggi tingkat social ekonomi akan menambah tingkat pengetahuan. Dalam soal mendapatkan informasi yang memerlukan biaya (misalnya sekolah), tingkat social ekonomi merupakan salah satu factor yang mempengaruhi tingkat pengetahuan seseorang, Semakin tinggi tingkat social ekonomi seseorang maka orang tersebut akan lebih mudah untuk mendapatkan informasi.

\section{Simpulan}

Berdasarkan hasil penelitian dan pembahasan tentang penggunaan kontrasepsi MOW menurut pengetahuan, pendidikan dan tingkat ekonomi/penghasilan dari akseptor di wilayah kerja Puskesmas Cidempet Kecamatan Arahan Kabupaten Indramayu tahun 2017, maka dapat disimpulkan :

1. Pasangan Usia Subur yang menggunakan alat kontrasepsi MOW sebagian besar adalah berpengetahuan baik yaitu sebanyak
46 Pasangan Usia Subur 79,3\%

2. Pasangan Usia Subur yang menggunakan alat kontrasepsi MOW sebagian besar adalah berpendidikan tinggi yaitu sebanyak 48 orang $(71,6 \%)$

3. Pasangan Usia Subur yang menggunakan alat kontrasepsi MOW sebagian besar adalah ekonomi atas yaitu sebanyak 47 orang $(70,2 \%)$.

4. Ada hubungan yang signifikan antara tingkat pengetahuan PUS dengan pemilihan alat kontrasepsi MOW di wilayah kerja Puskesmas Cidempet Kecamatan Arahan Kabupaten Indramayu tahun 2017 ( $p$-Value 0,000).

5. Ada hubungan yang signifikan antara tingkat pendidikan PUS dengan pemilihan alat kontrasepsi MOW di wilayah kerja Puskesmas Cidempet Kecamatan Arahan Kabupaten Indramayu tahun 2017 ( $p$-Value $0,000)$.

6. Ada hubungan yang signifikan antara tingkat ekonomi PUS dengan pemilihan alat kontrasepsi MOW di wilayah kerja Puskesmas Cidempet Kecamatan Arahan Kabupaten Indramayu tahun 2017 ( $p$-Value $0,000)$

\section{Saran}

1. Dalam mempertahankan dan meningkatkan mutu pelayanan bagi para akseptor dan calon akseptor $\mathrm{KB}$ diperlukan petugas keluarga berencana mampu memberikan pelayanan secara berkualitas dan professional, khususnya kepada PUS yang pengetahuan kurang, pendidikan rendah dan ekonomi bawah.

2. Dalam rangka mempertahankan dan meningkatkan program KB diperlukan kerjasama dari semua pihak, baik dari lintas maupun sektoral dalam memberikan penyuluhan kepada aseptor $\mathrm{KB}$ terutama kepada ekonomi bawah tentang tujuan dan manfaat dari program $\mathrm{KB}$ secara berkesinambungan.

3. Perlunya peningkatan pengetahuan kepada 
semua PUS baik pormal maupun non pormal dengan cara lintas program maupun lintas sektor melalui berbagai media secara berkesinambungan.

\section{Daftar Pustaka}

1. Noviana Hartika Sari. 2016. Hubungan Pengetahuan Ibu Dengan Penggunaan Alat Kontrasepsi IUD. Bandar Lampung : Fakultas Kedokteran Universitas Lampung (skripsi)

2. Sugiyono. 2002. Statistik untuk Penelitian. Bandung : Penerbit CV Alfabeta.

3. Arikunto,S. 2007. Prosedur Penelitian. Jakarta : Aneka Cipta

4. Notoatmodjo. 2010. Metodologi Penelitian Kesehatan. Jakarta : Rineka Cipta

5. Notoatmodjo, 2003. Pendidikan dan Perilaku Kesehatan. Jakarta : Rineka Cipta

6. Notoatmodjo. 2002. Metodologi Penelitian Kesehatan. Jakarta : Rineka Cipta

7. Notoatmodjo, 2003. Pendidikan dan Perilaku Kesehatan. Jakarta : Rineka Cipta

8. Notoatmodjo, 2005. Promosi Kesehatan Teori dan Aplikasi.Jakarta : Rineka Cipta

9. Notoatmodjo, 2007. Promosi Kesehatan danIlmu Perilaku.Jakarta : Rineka Cipta

10. Notoatmodjo. 2010. Metodologi Penelitian Kesehatan. Jakarta : Rineka Cipta

11. Arikunto,S. 2007. Prosedur Penelitian. Jakarta : Aneka Cipta

12. Noviana Hartika sari. 2016. Hubungan Pengetahuan Ibu Dengan Penggunaan Alat Kontrasepsi IUD. Bandar Lampung : Fakultas Kedokteran Universitas Lampung (skripsi) 